\title{
Workers of the World!
}

\author{
Winnie Lem ${ }^{1}$ - Anthony Marcus ${ }^{2}$
}

Published online: 10 November 2017

(C) Springer Science+Business Media B.V., part of Springer Nature 2017

Call for proposals

"Workers of the world, unite!" has incited working class people across the globe to act in concert to break the chains of exploitation and oppression. This anglicized and popularized version of the last sentence of the Communist Manifesto has galvanized workers in factories, mines, farms, and domestic service from Russia to the USA and from South Africa to Iran to coalesce into a class for itself in attempts to bring down capitalism. Written on the eve of the revolutionary wave in Europe in 1848, with the zeal and optimism that changing the social order would bring, the manifesto and this cry was the progressive pole of attraction around which even non-believers orbited during what Eric Hobsbawn, following Ivan Berend, called "the short twentieth century". Relentless class conflict from above, deteriorating class consciousness from below, and the collapse of the Soviet Union have seriously compromised the ability of the Workers of the World to think, act, and make history as a class for itself: all this despite the steady growth of the proletariat as a class in itself.

There appears to be a striking contradiction between an ever larger, more interconnected, and more important global proletariat and its crippling political weakness. Explanations for this converge on the schisms and ambiguities created by the international division of labor, neoliberal globalization, the rise of finance capital, the third industrial divide, post-fordism, the dominance of power elites, managerial society, the end of history, the post-industrial age, "clash of civilizations," and post-modernism. Strikingly, nearly all of the explanations that are popular in the media, academe, and "on the street" suggest evolutionary social dynamics that are, for the most part, external to the working class. Rarely are questions like political leadership, strategy, organizational method, institutional expression, or political program mentioned. Within the left in myriad countries across the planet such discussions, of course,

Winnie Lem

wlem@trentu.ca

1 International Development Studies, Trent University, Champlain College, Peterborough, ON K9J 7B8, Canada

2 Anthropology, John Jay College of Criminal Justice, New York, New York, USA 
continue, but they rarely are made explicit within the ambit of scholarly journals, academic research and the traditional intellectuals that make up social science.

To explore this central contradiction and the problem of the decomposition and recomposition of the working class, Dialectical Anthropology is launching a forum series - Workers of the World!

Each WoW! forum will focus on a regional or national setting and provide a platform for scholars, public intellectuals, activists and socialist partidarios to consider such topics as:

- the characteristics of the global proletariat

- the concerns that drive working class struggles in different global settings

- the impediments to acting as a class for itself

- what went wrong historically that brought us to the current impasse

- the forces that condition the movement of people in and out of wage work

- indigenous engagements in class struggle

- how workers come together in struggles around collective material interests

- the contemporary gendered dynamics of the global proletariat

- what and are not important institutional and political expressions

- labor struggles of the mobile proletariat

- big dangers confronting our social class in the current period

- the question of political leadership and revolutionary program

- organization, method and "the Leninism question"

We begin the series in the March 2018 issue with a provocation by Paul Durrenberger and Dimitra Doukas that discusses the failure of the US proletariat to confront their own national bourgeoisie in a united and effective way. Their provocation will be followed by commentaries from James Carrier, Julia Soul, Christopher Kelly, Manos Spyridakis, and Stephen Payne.

While many of us are tired of hearing about the latest problems and pronunciamentos from Planet Yank, such imperial rumblings cannot be ignored. The US state still guarantees the exploitation of the most strategic and important working class in the world. This can be measured easily by metrics such as yearly value production, stock market size, level of indebtedness, international investment, capitalization, military spending, number of military bases around the world, and global body count. Despite the rise of potential strategic competitors in Germany, China, and Russia, the USA remains the biggest problem for the reconstitution of the global proletariat, as a class for itself. As long as the custodians of the US State have impunity to decapitalize entire nations and send mercenary armies to all seven continents nobody is safe to live, breath, or resist. This impunity depends on the quiescence of the US working class. For this reason, we start in "the belly of the beast." However, we hope to move quickly to other regions and other social formations.

We invite proposals for forum statements and provocations and will actively assist individuals or groups that contribute in building a productive discussion involving varied contributors from within and beyond academic production sites.

Please send expressions of interest or a proposal of approximately 300 words to:

Winnie Lem (wlem@trentu.ca) or Anthony Marcus (amarcus@jjay.cuny.edu). 